\title{
Mesmerism, Sexuality, and Medicine: "Karezza” and the Sexual Reform Movement
}

\author{
Heinz Schott \\ University of Bonn, Bonn, Germany
}

\begin{abstract}
Within the scope of certain social and religious movements, mesmerism had a considerable impact on the American way of life during the last decades of 19th century. A famous example is the Christian Science of Mary Baker Eddy. But also less known groups adopted mesmeric ideas and practices. The paper focuses on the concept of "Karezza”. It combined a specific sexual practice with religious ideas of divine love, birth control, social reform, women's emancipation and health education. It was created by Alice Bunker Stockham (1833-1912), an obstetrician and gynecologist from Chicago. Among other authorities, the writer Leo Tolstoy and medical psychologist Havelock Ellis appreciated her approach. She was a pioneer of the sexual and marriage reform promoting practical advice for everyday life. As a doctor, she stressed especially the disastrous consequences of a brutal sexual life destroying body and mind (not only of the women). As an antidote, she propagated the "Karezza love" avoiding ejaculation ad a punctual orgasm (climax) during intercourse. The leading idea was the imagery of a mesmeric "fluidum” uniting individuals spiritually. Bunker's publications were translated into German. They corresponded to the Lebensreform movement, but never became popular. Also the early sexology about 1900 ignored Bunker's concept as well as the sexual medicine later on. It is worthwhile to reconsider it within the context of the history of medicine, culture, and anthropology.
\end{abstract}

Keywords: mesmerism, sexuality, Karezza, Alice Bunker Stockham (1833-1912), sexual reform, Lebensreform movement, women's emancipation

\section{Introduction}

Mesmerism founded by the medical doctor Franz Anton Mesmer during the 1770s in Vienna-then called "animal magnetism” (thierischer Magnetismus in German)—was a stimulating concept for science, medicine, and social life. Modified by the romantic natural philosophy and its psychological turn to the "unconscious" in the early 19th century, it played an essential role especially in medical practice before hypnotism and psychotherapy came up in the second half of the 19th century, when mesmerism was blamed for its "occultism" and "mysticism" by the scientific community. But within the popular (and very heterogeneous) movements of naturopathy (Naturheilkunde) and life reform (Lebensreform) linked with the Art Nouveau (Jugendstil) the impact of mesmeric ideas and practices was amazing. Especially the "natural" or "spiritual" healing method and the sentiment of merging in a group were attractive for religiously motivated communities. Their activities

Heinz Schott, MD, Ph.D., Emeritus Professor of the History of Medicine, Institute of the History of Medicine, University of Bonn.

Correspondence concerning this article should be addressed to Prof. Heinz Schott, Institute of the History of Medicine, Sigmund-Freud-Str. 25, D-53105 Bonn, Germany. E-mail: Heinz.Schott@ukb.uni-bonn.de. 
aimed generally for an improvement of social misery regarding e.g. the situation of (poor) women without birth control and often handed over to sexual violence. In the following case study we will consider the performance of a medical doctor with her outstanding concept of humanely domesticated sexuality.

Alice B. Stockham (1833-1912) was an obstetrician and gynecologist from Chicago, an enthusiastic fighter for a marital and sexual reform. "Karezza" was taken from the Italian term "carezza" (written with a "c") meaning petting or very gently striking. Stockham was the fifth woman in the U.S.A., who got the degree of a Medical Doctor. Apart from her special field gynecology and obstetrics she was engaged in charity and interested in spiritual topics. She also practised homeopathy, fought against alcoholism, served probably sometimes as a trance medium and was an active feminist, a suffragette. ${ }^{1}$ In 1886, she published a book on the health of women: Tokology. A Book for Every Woman "with several editions and translations into foreign languages". Lev Tolstoi, a friend of Stockham, was so impressed, that he initiated a translation of the book into Russian and wrote a preface. ${ }^{2}$ He supported her approach wholeheartedly. In 1900, she published by her own press the study "Tolstoi-A Man of Peace”, together with the Tolstoi study of Havelock Ellis, the well-known English sexologist.

\section{Stockham's Concept of Karezza}

Stockham adhered to the so called "New Thought Movement". In 1886, she joined the first course on Christian Science organised by Emma Hopkins in Chicago. Many renowned women supported this movement, which was separated into two parties. One party refused strictly any sex appeal, whereas the other one backed by Stockham tried to let it worthily perform. ${ }^{3}$ In 1896, she published in her own press a book titled, Karezza. Ethics of Marriage. ${ }^{4}$ A German translation appeared one year later. The translator, a certain Dr. Hartung, general practitioner in Silesia, praised Stockahm as a "soul-curing physician of mankind authorized by her science". ${ }^{5}$ He just stressed in his preface Stockham's principles of healing and nutrition without mentioning her natural philosophical and religious ideas. ${ }^{6}$ The well known Swiss life reformer and naturist Werner Zimmermann translated it once again almost 30 years later. ${ }^{7}$

Stockham was convinced, that there was a tremendous difference between the usual copulation and the Karezza conjunction or merging. She opposed them fundamentally as the following quotations show: "The ordinary hasty spasmodic method of cohabitation, for which there has been no previous preparation, and in which the wife is passive is alike unsatisfactory to husband and wife. It is deleterious both physically and spiritually. It has in it no consistency as a demonstration of affection, and is frequently a cause of estrangement and separation.”8 In contrast the Karezza merging would be satisfactory, healthy, and heaven on earth: "During

${ }^{1}$ http://www.reuniting.info/wisdom/stockham_karezza (14.12.2010).

2 Beryl Sattler: Each Mind a Kingdom. American Women, Sexual Purity, and the New Thought Movement, 1875-1920. Berkeley; Los Angeles; London: University of California Press, 1999, p. 136.

3 Ibid., diagram.

4 Alice Bunker Stockham: Karezza. Ethics of Marriage. Chicago: A. B. Stockham \& Co., 1896; online: http://babel.hathitrust.org/cgi/pt?id=nyp.33433075969281;view=1up;seq=13 [page numbers in brackets refer to EPUB online: http://www.globalgrey.co.uk/Pages/Books-Sacred-Sexuality/Karezza-Ethics-Of-Marriage.html\#.VFVPFxZ4D8g].

5 Alice Bunker Stockham: Die Reform-Ehe. Ein Mittel zur Erhöhung der Daseinsfreude und zur Veredelung des Menschengeschlechts. Autorisirte deutsche Uebersetzung von H. B. Fischer. Vorrede: Dr. Hartung. Hagen i.W.: Risel, 1897, p. VII.

${ }_{7}^{6}$ Ibid., pp. IX-XI.

7 Alice Bunker Stockham: Ethik der Ehe. Karezza. Berechtigte Übersetzung aus dem Amerikanischen von Werner Zimmermann. Jena; Bern: Die Neue Zeit, 1925.

${ }_{8}$ Alice Bunker Stockham: Karezza. Ethics of Marriage [originally published in 1896]. New and revised edition. New York. Fenno, ca. 1903, p. 23 [p. 8]. 
a lengthy period of perfect control, the whole being of each is merged into the other, and an exquisite exaltation experienced. This may be accompanied by a quiet motion, entirely under subordination of the will, so that the thrill of passion for either may not go beyond a pleasurable exchange. [...], with abundant time and mutual reciprocity the interchange becomes satisfactory and complete without emission [i.e. ejaculation] or crises. In the course of an hour the physical tension subsides, the spiritual exaltation increases, and not uncommonly visions of a transcendent life are seen and consciousness of new powers experienced."9

Stockham combined a vitalistic principle with a spiritualistic or mental one. She argued, that the "creative power" or "energy“ could and should be mentally controlled and ruled. In her opinion, the human was free to choose "voluntarily and consciously [...] between these two roads, - the spiritual or material". ${ }^{10}$ In fact: "Religion and philosophy are required in consecrating passion." ${ }^{11}$ Her key sentence or motto claimed: "In no way does man's dominion yield him richer return than in control, mastery and consecration of sex energy. [...] Through love, training and self-control [...] the married may not only attain the same conservation and appropriation [as the unmarried] but also by the union of the spiritual forces of their two souls, greatly augment them." 12 Stockham stressed the positive effects of those forces: "There is no limit to the power of a true soul union. It specifically increases the gift of healing and may be purposely directed to free a friend from pain and suffering."13 "Karezza” would signify "to express affection in both words and actions". So, it was "used technically [...] to designate a controlled sexual relation". ${ }^{14}$

Stockham described this love technique rather exactly and distinguished it from other techniques, which might be confused with Karezza. So she pointed out, that in her book Tokology, she had erroneously referred to "Sedular Absorption". ${ }^{15}$ But now she highlights: "in Karezza, there is no seed to be absorbed, as, under the direct control of the will, the act ceases short of the seed secreting period". She criticized also the term "Male Continence”, because Karezza required a female continence as well.

She called it "a symbol of the perfect union of two souls in marriage, it is the highest expression of mutual affection, and gives to those practicing it revelations of strength and power." ${ }^{, 16}$ Karezza would contribute to "individual development and formation of character" and would not lead to "ascetism and repression". 17 Stockham argued like all contemporary life reformers and race biologists naturalisticly and quoted according to the English evolutionary theorist Herbert Spencer the "law of being" (i.e. the "law of nature") the following of which ends up in pleasure, whereas "all our sufferings come from ignorance of the law of being". ${ }^{18}$ Stockham stressed again and again, that Karezza was really possible. In the supplement of her book headed Corroboration she quoted from hundreds of letters some "testimonies" for evidence of her doctrine. ${ }^{19}$ "At all times to subordinate physical senses and desires to the spiritual is a matter of education and growth in the knowledge of the laws of being-a knowledge of the power of the spiritual nature."20

9 Ibid., p. 26 [p. 9].

${ }^{10}$ Ibid., p. 10 [p. 3].

11 Ibid., p. 17 [p. 6].

12 Ibid., p. 20 [p. 6].

13 Ibid., p. 20 [p. 7].

${ }_{15}^{14}$ Ibid., p. 22 [p. 8].

15 Ibid., p. 26 [p. 9].

16 Ibid., p. 27 [p. 10].

17 Ibid., p. 28 [p. 10].

18 Ibid., p. 31 [p. 11].

19 Ibid., pp. 113-140 [pp. 45-61].

${ }^{20}$ Ibid., p. 32 [p. 12]. 
Stockham did not respond to the then well-known techniques of hypnosis and suggestion. But she complied implicitely with their principles. All physiological functions and vital processes could be influenced "by a voluntary mental effort". ${ }^{21}$ She criticized the doctrine, according to which those physiological functions would work automatically and were inflexibly fixed. She was aware of the imagination, which was ascribed to the placebo effect later on: "The thought of some stimulant or medicinal preparation has an effect similar to that of the thing itself, even if less in degree."22 Karezza would teach the "supreme action of the will over the sexual nature, as well as the complete appropriation of the creative energy to high aims." ${ }^{23}$ The retention and absorption of the semen would strengthen the male organism and add "enormously to man's magnetic, mental and spiritual force." ${ }^{24}$ She disclaimed the traditional dogma whereby the retention of seminal fluid is harmful.

In the view of Stockham, Karezza was a panacea with great therapeutic value "not equalled by any remedy of pharmacopoeia, or by any system of healing". ${ }^{25}$ She praised the ideal of marital love: "the truly married consummate this union with perfect freedom and naturalness. ${ }^{26}$ Finally, Stockham's sexual doctrine focussed on the fulfilment of natural laws. She did not demand the repression of the sexual instinct, but viewed sexuality as a deep bond of the human with the macrocosm, the whole world. Karezza would conduce "to the building of character and spiritual growth and at the same time the sexual functions are honoured, refined and dignified". ${ }^{27}$ Obviously, as a practicing doctor, Stockham was a sought-after counsellor for problems of matrimony and sexuality. She encouraged numerous people to practice the Karezza method.

She referred to a series of other authors publishing about 1900 in the United States. Obviously, in this "country of unlimited possibilities", Karezza appeared to be much more attractive than elsewhere, especially in Europe, because its concept combined natural philosophical, eugenic, and especially religious motives. So, Stockham edited the already in 1890 anonymously published novella. The Strike of a Sex and Zugassent's Discovery by George Noyes Miller, a former member of the Oneida Community, mentioned by some correspondents in her Karezza book. ${ }^{28}$ Moreover, she pointed to other protagonists of the American sexual reform movement like Henry Wood, Warren F. Evans und Ursula N. Gestefeld.

Miller's hero of his novella Immanuel Zugassent discovers the physiological and spiritual benefit by conscious control of the sexual function. The author compared Zugassent's Discovery with scientific-technical innovations at that time like steam-engine, electricity, and telephone. ${ }^{29}$ This discovery able to reduce human misery would even dwarf discoveries like those of Jenner, Harvey, Pasteur, or Koch. ${ }^{30}$ Miller’s quasi religious plea for a spiritual domestication of the animal instinct addressed mainly the social calamity produced by the lack of birth control. At the same time, Miller relied on the practice of mesmerism and hypnotism which he did not discern. But that confusion was quite common in the contemporary folk or lay medicine. Miller's position implied certain social political and social medical objectives corresponding to Stockham's approach. When Zugassent explains that all experiences would show "the power of the will over the involuntary processes of the

${ }^{21}$ Ibid., p. 34 [p. 12].

22 Ibid., p. 35 [p. 13].

23 Ibid., p. 38 [p. 14].

24 Ibid., p. 43 [p. 16].

${ }^{25}$ Ibid., p. 48 [p. 18].

26 Ibid., p. 83 [p. 32].

27 Ibid., p. 85 [p. 33].

${ }^{28}$ Ibid., 106-133 [pp. 54-57]; George Noyes Miller: The Strike of a Sex and Zugassent's Discovery, or after the Sex Struck. New and rev. ed. Chicago, Ill.: Stockham Publishing, 1905 [“Zugassent’s Discovery” cf. pp. 93-118].

${ }^{29}$ Miller, ibid., p. 109

30 Ibid., p. 103. 
body", this reminds us of James Braid's key formula, namely "the power of the mind over the body" ${ }^{31}$ Miller argued in the sense of naturopathy (Naturheilkunde) and marital reform aiming at a conscious birth control. The dissipation of life and nerve force by uncontrolled sexuality might be one day assumed to be as absurd as the traditional bloodletting in the past. ${ }^{32}$ Instead of such a devious practice, "the innocent magnetic exchange" should intervene between the marital partners. This was also named "sexual magnetism" leading to the highest spiritual growth, also to "welfare and happiness of others", and participating in the divinity. ${ }^{33}$ The sexual self-control was compared with the performance of a boatman on a stream showing first quiet water, then rapids and finally a waterfall. Now, it depends on the skill of the boatman, how far he dares to approach the waterfall without losing the control and being pulled down into the abyss. His skill has to confine "his excursions to the region of easy rowing”. ${ }^{34}$

\section{The Reception of Stockham's Work}

There were a very few celebrities appreciating Stockham's Karezza method. We should mention at the first place the Russian writer Leo Tolstoy, a personal friend of Stockham as already noted. Another authority being open minded to Karezza was the English sexologist Havelock Ellis, who corresponded also with Sigmund Freud on the problem of sexuality and anticipated the concept of auto-erotism and narcissism. Freud cited him often, especially in his Interpretation of Dreams. It is remarkable but not astonishing, that Freud himself did not take any notice of Stockham, who did not belong in academia. But much more astonishing is the fact, that sexology (Sexualwissenschaft) and sexual medicine (Sexualmedizin) enfolding in the early 20th century and also the respective scientific debate following the so-called sexual revolution of the 1960s ignored Karezza almost completely. Even the recent feministic movement and the correspondent gender debate forgot about Stockham.

In general, Stockham's work seemed to be suspicious, either for biological reasons as an inappropriate method of sexual satisfaction or for moral reasons as an unnatural method contradicting divine laws. The most prominent opponent for moral reasons was the papal authority. Forty years after her death in 1912, Pope Pius XII. rejected a so-called "reserved embrace" referring indirectly to Karezza, which was forbidden for priests and spiritual directors to recommend. In his “allocution to midwives” in 1951, he cited Pope Pius XI's Encyclical Casti Connubii (chaste wedlock) in 1930: “...that every attempt of either husband or wife in the performance of the conjugal act or in the development of its natural consequences which aims at depriving it of its inherent force and hinders the procreation of new life is immoral and that no 'indication' of need can convert an act which is intrinsically immoral into a moral and lawful one. The precept is in full force today, as it was in the past, and so it will be in the future also, and always, because it is not a simple human whim, but the expression of a natural and divine law. ${ }^{, 35}$

I think it's worthwhile to remember Alice B. Stockham, an outstanding doctor and philanthropist, who practised in a humanistic manner in Chicago fighting for a better life, and who died here about 100 years ago. Apart from her published writings, I could not detect any archival material like correspondences or manuscripts

\footnotetext{
31 James Braid: The Power of the Mind Over the Body.1846. In: Readings in the History of Psychology. Compiled and edited by Wayne Dennis. New York. Appleton-Century-Crofts, 1948, pp. 178-193.

${ }^{32}$ Miller, ibid., p. 111.

33 Ibid., p. 118.

${ }^{34}$ Ibid., p. 113.

35 http://en.wikipedia.org/wiki/Alice_Bunker_Stockham\#cite_note-5 (Sept. 29, 2014).
} 
in the United States or elsewhere. I was told, that nothing is left in any US repository. Please, contact me, if you know anything about unknown material. Nevertheless, it is remarkable, that in certain esoteric circles her Karezza book is still on sale. It is time, that the scientific community recognizes her important idea of a spiritual or mental emancipation from sexual bestiality. I think, that Stockham may become a fascinating figure for the medical and cultural historiography in the overlapping areas of natural philosophy and religious thinking, mesmerism and psychoanalysis, medical anthropology and sexology, feminism and social hygiene, and last but not least humanism and pacifism. It is time to rediscover her life and work.

\section{Conclusion}

Stockham's concept of Karezza poses a great challenge for modern sexology and sexual medicine: It follows another anthropology than science and medicine do since the late 19th century, when biology and naturalism impressed by Darwinism and the experimental (natural) sciences ignored the power of the mind over bodily functions. So, sexuality, in particular sexual intercourse and orgasm, were understood as quasi automatic physiological processes, involuntary reflex mechanisms. This biologistic view predominated also sexology and the sexual reform movement in the early 20th century up to the so-called sexual revolution starting in the 1960s. Sexual emancipation was then thought as the liberation from the (bourgeois) moralistic inhibition of the living out the sexual instinct. Therefore, the Karezza method opposing those doctrines means a unique alternative to cultivate sexual practice as a voluntary social act. Investigating the history of this idea within its cultural and scientific context may become essential for reflecting the anthropological conditions of sexuality today.

\section{References}

Miller, G. N. (1905). The strike of a sex and Zugassents' discovery, or after the sex struck. (New and rev. ed.). Chicago, Ill.: Stockham Publishing.

Pius XII (Pope). (1951). Nature of their profession. Allocation to midwives, October 29, 1951. Retrieved September 29, 2014, from https://www.ewtn.com/library/PAPALDOC/P511029.HTM http://en.wikipedia.org/wiki/Alice_Bunker_Stockham\#cite_note-5)

Sattler, B. (1999). Each mind a kingdom. American women, sexual purity, and the new thought movement, 1875-1920. Berkeley; Los Angeles; London: University of California Press.

Stockham, A. B. (1896). Karezza, ethics of marriage. Chicago, Ill.: A. B. Stockham \& Co.—New and revised edition (ca. 1903). New York: R. F. Fenno \& Co. 